\title{
On the modeling paradigm of plant root nutrient acquisition
}

\author{
Jinyun Tang $\mathbb{D} \cdot$ William J. Riley
}

Received: 10 September 2020 / Accepted: 7 December 2020 / Published online: 14 January 2021

(C) The Author(s) 2021

\begin{abstract}
Plant root nutrient acquisition, and to a lesser extent foliar nutrient uptake, maintain plant metabolism and strongly regulate terrestrial biogeochemistry and carbon-climate feedbacks. However, terrestrial biogeochemical models differ in their representations of plant root nutrient acquisition, leading to significantly different, and uncertain, carbon cycle and future climate projections. Here we first review biogeochemical principles and observations relevant to three essential plant root nutrient acquisition mechanisms: activity of nutrient acquiring proteins, maintenance of nutrient stoichiometry, and energy expenditure for these processes. We next examine how these mechanisms are considered in three existing modeling paradigms, and conclude by recommending the capacity-based approach, the need for observations, and necessary modeling developments of plant root nutrient acquisition to improve carbonclimate feedback projections.
\end{abstract}

Keywords Plant root nutrient acquisition $\cdot$ Nutrient limitation · Biogeochemistry-climate feedback · Plantmicrobial competition $\cdot$ Nutrient stoichiometry .

Terrestrial biogeochemical modeling

Responsible Editor: Philip John White.

J. Tang $(\bowtie) \cdot$ W. J. Riley

Climate and Ecosystem Sciences Division, Lawrence Berkeley

National Laboratory, Berkeley, CA 94720, USA

e-mail: jinyuntang@lbl.gov

\section{Introduction}

Since plants often live in environments with a limited supply of macronutrients (i.e., nitrogen and phosphorus), they must actively acquire these nutrients to fulfill their metabolic needs, such as surviving environmental stress, increasing biomass, and producing offspring (e.g., Cronan 2018). Plants procure these nutrients primarily by roots, through complex interactions and competition with soil microbes, other plants, and abiotic processes. A smaller proportion of these nutrients are obtained via foliar nutrient uptake (Fernandez and Brown 2013; Lambers et al. 2009; Sparks 2009; Wittwer and Teubner 1959). In order to predict how plants and therefore terrestrial ecosystems interact with the changing environment, modelers have developed and implemented various plant root nutrient acquisition paradigms in terrestrial biogeochemical models (Achat et al. 2016). Nonetheless, despite decades of research, there has been no consensus on which paradigm to use in terrestrial biogeochemical models (Wang et al. 2010; Yang et al. 2014; Zhu et al. 2017), resulting in large uncertainty, and degrading the fidelity of biogeochemistry-climate feedback projections (e.g., Fleischer et al. 2019).

We identified three paradigms (or approaches) that have been used to conceptualize and simplify the very complex process interactions affecting plant root nutrient acquisition: (1) the relative demand approach (Goll et al. 2012; Hidy et al. 2016; Wang et al. 2010; Yang et al. 2014); (2) the capacity-based approach (Medvigy et al. 2019; Tang and Riley 2013; Yu et al. 2020; Zhu et al. 2016), and (3) the much less used thermodynamic 
flow-force approach (Le Deunff et al. 2019; Thellier et al. 2009). The relative demand approach assumes that, in acquiring a given nutrient, the capabilities of all competitors are instantaneously proportional to their respective nutrient demands, which for plants are driven by their attempt to maintain stoichiometric balance under nutrient dilution caused by $\mathrm{CO}_{2}$ assimilation.

In the capacity-based approach, plants spend metabolic energy or take advantage of the chemical potential gradient of nutrient molecules inside and outside root (or mycorrhizal) surfaces to acquire nutrients via special nutrient acquiring proteins (pumps, transporters, and channels; Taiz and Zeiger 2006). In this approach, microbes and abiotic competitors, such as mineral surfaces, are analogously characterized with acquisition capabilities (i.e., how effective and how fast nutrients can be acquired).

In the thermodynamic flow-force approach (derived from non-equilibrium thermodynamics; Thellier 1971), plant root nutrient acquisition also follows the chemical potential gradient of nutrient molecules inside and outside the roots (or mycorrhizae) with associated conductance parameters determined by environmental conditions and plant traits.

Among these three approaches, an important distinction is that for both the capacity-based approach and the thermodynamic flow-force approach, plant root nutrient acquisition is tied to root activity, and can occur in the absence of photosynthesis. In contrast, the relative demand approach is implemented without explicitly considering root activity. Recently, Riley et al. (2018) implemented both the relative demand approach and the capacity-based approach in the terrestrial biogeochemical module of the Energy Exascale Earth System Model (E3SM), and found that these two approaches resulted in large differences in predicted global $\mathrm{N}_{2} \mathrm{O}$ emission warming potential $\left(2.4 \mathrm{Pg} \mathrm{CO}_{2} \mathrm{yr}^{-1}\right.$ ) and nitrogen leaching (96\% difference), highlighting the need to develop an accurate and mechanistically realistic plant root nutrient acquisition paradigm to improve modeling of biogeochemistry-climate feedbacks.

In this opinion piece, we review the soil and plant biogeochemistry and competition processes affecting plant root nutrient acquisition, synthesize existing observations, examine how related mechanisms are resolved in the three modeling approaches, and conclude by discussing the need for observations and how terrestrial biogeochemical models can update their paradigms to better represent the relevant mechanisms. Although our review of biological mechanisms below is succinct, we believe it is sufficient to recommend a paradigm of plant root nutrient acquisition amenable to terrestrial biogeochemical models. For discussions of detailed molecular-level biological mechanisms, including plant shoot-root development, molecular sensing of nutrient molecules, and plant-mycorrhizal interactions, we refer readers to other excellent reviews (e.g., Gent and Forde 2017; Lambers et al. 2009; Oldroyd and Leyser 2020).

\section{Biogeochemical processes controlling plant root nutrient acquisition}

Plant root nutrient acquisition occurs in soil through competition with microbes and abiotic competitors (Fig. 1), all of which are modulated by transport (e.g., diffusion, dispersion and advection; Tinker and Nye 2000). In this review we do not discuss how plants spend energy on growing roots or mycorrhizae, but note that these processes are also critical for modeling plant root nutrient acquisition, and are often (implicitly) considered in models as part of the plant allometric relationships for carbon and nutrients (e.g., Zhu et al. 2019). Mechanistically, both plant and microbial nutrient acquisition involve three broad and closely coupled classes of biogeochemical processes: (NA1) activity of nutrient acquiring proteins, (NA2) maintenance of nutrient stoichiometry, and (NA3) energy expenditures for these processes. These three processes are asynchronous in plants (as we explain in more detail below) because of their size and the time taken to transport carbon and nutrients from one plant organ to another (e.g., Taiz and Zeiger 2006). In contrast, by being much smaller, microbes have shorter time lags between expressing a nutrient acquiring protein and securing nutrient molecules with that protein (Madigan et al. 2009), justifying the synchrony assumption often made in models like ecosys (Grant 2013) which uses a 60 minute time step or the global-scale models like ELM (Zhu et al. 2019) and CLM (Lawrence et al. 2019) which use a 30 minute time step. However, for some fungi having effective hyphae lengths comparable to those of plant roots, asynchrony may become important (e.g., Watanabe 2002). Moreover, when nutrients are abundant, microbes produce storage materials, which may be used to fuel survivial under prolonged starvation (Ji et al. 2015).

The first class of nutrient acquisition processes, NA1, can be divided into three components: (NA1a) use of 
different nutrient acquiring proteins for different nutrient molecules, (NA1b) environmental modulation of the activity of these proteins, and (NA1c) trade-offs among these protein activities. An example of NAla is that plants can take up and assimilate different nitrogen forms (e.g., ammonium, nitrite, nitrate, urea, amino acids), often with preference (e.g., MasclauxDaubresse et al. 2010; Miller and Cramer 2004). Consequently, the nitrogen forms plants and microbes acquire depend strongly on the soil physical and biogeochemical conditions that determine the bioavailability of related molecules or ions (i.e., NA1b). In low $\mathrm{pH}$ and anaerobic natural soils, ammonium produced from organic matter decomposition is the primary nitrogen form. Under aerobic or high $\mathrm{pH}$ conditions, rapid nitrification can make nitrate the primary inorganic nitrogen form (Miller and Cramer 2004). In cold environments, such as tundra and boreal forests where organic matter mineralization is so slow that inorganic nitrogen forms become limiting, amino acids may serve as an important form for plant root nutrient acquisition (Nasholm et al. 2009). In agricultural ecosystems, besides ammonium and nitrate, urea from fertilizers may become an important nitrogen source, although it may be hydrolyzed into ammonium before it is assimilated for biomass (e.g., Pinton et al. 2016; Witte 2011).

Similar to diauxic microbial growth on different carbon substrates (i.e., because of NA1b) (Erickson et al. 2017; la Cecilia et al. 2019), plants respond to different soil nitrogen forms by regulating the expression of corresponding nutrient acquiring proteins to enhance or repress the uptake of one nitrogen form over another (NA1c; Miller and Cramer 2004). For instance, nitrate is often found to suppress ammonium uptake, even though using ammonium for biomass synthesis costs plants less energy (Lee and Drew 1989). In crop plants, simultaneous application of urea and nitrate is found in the short term to lower nutrient acquiring protein expression for both nitrogen forms compared to when they are applied alone (Zanin et al. 2015). However, in the long term, crop plants grow better and increase their nitrogen use efficiency when both nitrate and urea are applied (Pinton et al. 2016). Besides diauxic growth on different nutrients, trade-offs among different nutrient acquiring proteins may also arise from the competition of metabolic energy required for plant root nutrient acquisition (i.e., NA3), such that more uptake of one form often lowers the uptake of others. Additionally, because the oxidation of organic carbon produces metabolic energy, this energy trade-off also explains why assimilating organic nitrogen may increase overall nitrogen use efficiency (Franklin et al. 2017).

Energy required for plant root nutrient acquisition is provided by ATP (or proton motive force) harvested from root respiration using either photosynthates or carbon from the acquired organic nutrient (Franklin et al. 2017; Masclaux-Daubresse et al. 2010). For intracellular processes, nitrogen is primarily used to construct proteins and nucleotides (and some forms may be used as signal molecules, e.g., nitrate and nitrite (Maathuis 2009)), and the energy cost for assimilating each nitrogen form may be approximately ranked by their reduction status with respect to the nitrogen valence in the amino group. However, with the extra energy incurred to handle indirect biochemical feedbacks, such as maintaining cellular $\mathrm{pH}$ homeostasis accompanying ammonium or nitrate assimilation or energy produced from oxidizing the extra carbon associated with the organic nitrogen (Feng et al. 2020), the actual energy cost (and therefore efficiency) for nitrogen assimilation may differ from this ranking in a given environment (Franklin et al. 2017; Raven and Smith 1976).

Unlike microbes that can directly assimilate phosphorus from dissolved small organic molecules (van Veen et al. 1987), plants primarily take up inorganic soil phosphorus (i.e., dissolved and dissociated forms of $\mathrm{H}_{3} \mathrm{PO}_{4}$, aka $\mathrm{Pi}$; but see Mckercher and Tollefson (1978) for exceptions), which is provided either by external sources or organic matter mineralization. Therefore, plant phosphorus acquisition is limited by factors regulating soluble Pi availability, such as phosphatase activity, sorptive interactions with abiotic mineral soil surfaces, $\mathrm{pH}$, etc. (Schachtman et al. 1998). Indeed, the soluble Pi form is a strong function of $\mathrm{pH}$ (with $\mathrm{pK}=2.1$ for $\mathrm{H}_{3} \mathrm{PO}_{4}$, and 7.2 for $\mathrm{H}_{2} \mathrm{PO}_{4}^{-}$, respectively). Consequently, for a typical soil $\mathrm{pH}$ of $6.0, \mathrm{H}_{2} \mathrm{PO}_{4}^{-}$dominates, followed by $\mathrm{H}_{3} \mathrm{PO}_{4}$ and $\mathrm{HPO}_{4}^{2-}$. Corresponding to this ranking of $\mathrm{Pi}$ availability, most studies observe that plants primarily take up $\mathrm{H}_{2} \mathrm{PO}_{4}^{-}$(e.g., Furihata et al. 1992). Similar to nitrogen, plant root phosphorus uptake is also regulated by the coupling between three processes (Fig. 1) as a function of substrate bioavailability in different soil conditions (Bucher et al. 2001; Smith 2002). 


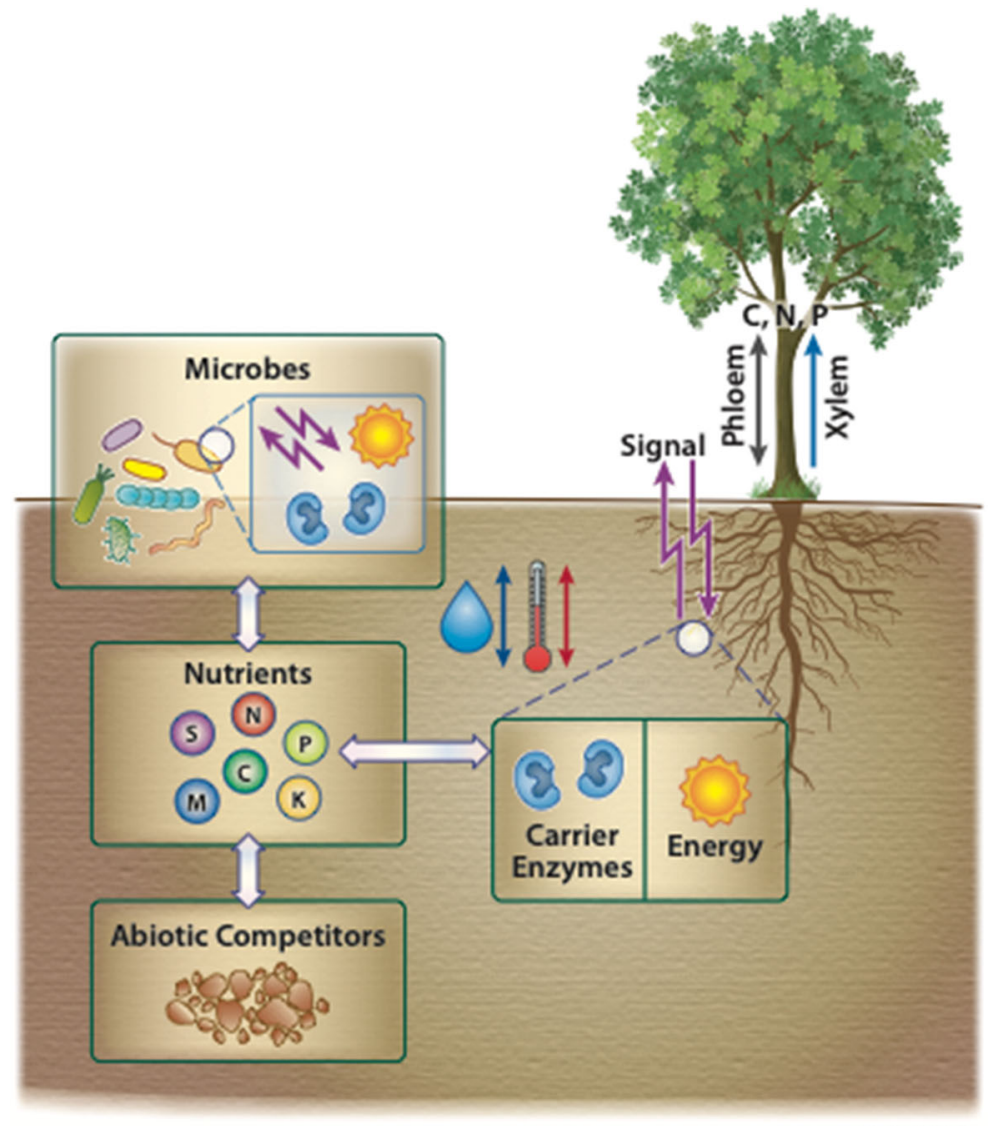

EESA19-055

Fig. 1 Plant root nutrient acquisition involves the coupling of three classes of processes: (NA1) activity of nutrient acquiring proteins (i.e., pumps, transporters, and channels distributed over the lipid bilayer membrane of root or mycorrhizal cells, and is typified by light blue carrier enzymes), (NA2) maintenance of nutrient stoichiometry (which signals nutrient demand as indicated by purple arrows), and (NA3) energy expenditure (indicated by the orange sun-shape). Plant root nutrient acquisition occurs in

Molecular measurements suggest that both plant and microbial cytosolic nutrient concentrations are usually higher than those in soil solutions (e.g., Miller and Cramer 2004). Therefore, to facilitate the countergradient movement of nutrient molecules (e.g., NA3 supports NA1), transport across the plasma membrane is generally through energy-driven (in the form of ATP or proton motive force dissipation) pumps or transporters, except for neutral nutrient molecules (e.g., $\mathrm{NH}_{3}$ ) that enter root cells through channels (Niemietz and Tyerman 2000). This energy cost and its relationship with energy producing substrates constrain the speed and location where nutrients can be assimilated. For plants, since photosynthesis and plant root nutrient soil through competition with microbes and abiotic factors (such as physical-chemical immobilization), all of which are regulated by physical transport (e.g., diffusion and advection), temperature (red two-sided arrow), and moisture (blue two-sided arrow). Depending on energy expenditure, plant root nutrient acquisition is strongly regulated by xylem (blue upper arrow) and phloem (gray two-sided arrow) transport of carbon and nutrients between shoots and roots

acquisition are physically distant, there is a significant time-lag between carbon fixed in leaves and its use for root biomass growth and energy expenditure (i.e., NA3 in roots). In addition, because the shoot-root carbon transfer is distance dependent, this time-lag often increases with plant size, so that generally the taller the plant, the older the carbon used by roots to generate energy (Mencuccini and Holtta 2010). Accordingly, plant root nutrient acquisition is constrained by how fast leaf carbon can be transported to roots through phloem and thus becomes correlated with transpiration (through the flow coupling between phloem and xylem) and soil water flow (by further coupling with nutrient transport; Houshmandfar et al. 2018; Taiz and Zeiger 2006), 
explaining why girdling may slow plant root nutrient acquisition (Jordan et al. 1998).

Plants move mobile nutrients like nitrate, amino acids, and Pi taken up by roots through xylem to leaves for assimilation (NA2; e.g., Tegeder and MasclauxDaubresse 2018). Organic nutrients may move with carbon through the phloem, but generally at a lower speed than in xylem (Jensen et al. 2016). Overall, since phloem and xylem flows are on the order of $10^{-3} \mathrm{~m} \mathrm{~s}^{-1}$ or less, plant root nutrient acquisition and photosynthesis are probably asynchronous even in the short term (days). Consequently, processes that adjust nutrient stoichiometry (NA2) are not as closely coupled to the other two plant root nutrient acquisition processes as in microbes for typical numerical time steps used by terrestrial biogeochemical models. The usually large distance between carbon source and use also explains why plants with foliar nutrient uptake may possess an advantage for canopy development, a phenomenon that has significant ramifications for cropping and certain natural ecosystems, but is missing in most models we are aware of (Al Harbi et al. 2013; Kannan and Charnel 1986; Sparks 2009).

From the processes reviewed above, we thus infer that the overall plant nutrient stoichiometry emerges dynamically from the elemental composition of different cells in the various organs (Taiz and Zeiger 2006). Indeed, plant stoichiometry is often measured at the level of organs (Kattge et al. 2011), such as leaves, stems, roots, etc. In contrast, many terrestrial biogeochemical models assume that each plant organ has fixed nutrient stoichiometry, and plants maintain the overall nutrient balance (i.e., NA2) through energy-dependent translocation of internal nutrients and assimilation from external sources (e.g., Wang et al. 2010; Yang et al. 2014). However, because of the coupling among the three classes of processes, at the cellular-level, plant nutrient stoichiometry should vary in ways similar to that of single-cell microbes. Microbes modify their internal nutrient concentrations and macromolecular compositions to adapt their growth rates to changes in environmental conditions (Garcia et al. 2016; Madigan et al. 2009), while for newly formed cells in a plant organ the environmental conditions are established mostly by existing neighbor cells. Even when cells built from new photosynthates can maintain nutrient stoichiometry using nutrients translocated from their neighbors, because nutrient translocation takes time, and such time is longer for plants of greater sizes, the nutrient stoichiometry of a plant organ and consequently the whole plant will fluctuate in response to fluctuating environmental conditions (Jing et al. 2017; Taiz and Zeiger 2006). In summary, plant and soil biogeochemistry together make plant nutrient uptake and nutrient use for forming new biomass intrinsically asynchronous.

\section{Observations revealing photosynthesis-independent plant root nutrient acquisition}

A major inference we derive from the biogeochemical processes reviewed above is that photosynthesis and root nutrient uptake in plants are intrinsically asynchronous. We next corroborate this assertion with observations of diurnal and seasonal plant root nutrient acquisition dynamics.

We identified 14 experiments (Table S1) that measured the diurnal cycle of plant root nutrient acquisition in crops. For example, Pan et al. (1987) studied nitrate, potassium, and phosphate uptake by seedlings of five corn genotypes, and Okuyama et al. (2015) observed nitrogen and potassium absorption by cucumber, komatsuna, tomato, and water spinach. Most experiments, except Okuyama et al. (2015), collected measurements using artificial light conditions and nutrient solutions without soil, and we found no measurements of diurnal plant root acquisition of phosphate in soil. For natural ecosystems, we only found one observational study (Schimel et al. 1989) that measured nighttime and daytime cumulative ammonium and nitrate uptake by plants and microbes in a grassland ecosystem.

For the diurnal cycle reported in Okuyama et al. (2015; Fig. 2a), cucumber nitrate uptake showed two peaks, one in the light and one in the dark. Others observed similar patterns using artificial light sources (e.g., Pan et al. 1987). Albornoz and Lieth (2015), who switched plants between constant light and dark conditions in their experiments, observed more than three diurnal peaks for almost all nutrients studied. Although it is hard to extrapolate these patterns observed in greenhouses to field conditions, these many studies we identified showed that $30 \sim 60 \%$ of plant root nutrient acquisition occurred during the night; that is, none of these observations showed that plant root nutrient acquisition is synchronous with photosynthesis (Table S1). These crop-based studies also observed significant nighttime plant root nutrient efflux, a process that likely occurs 


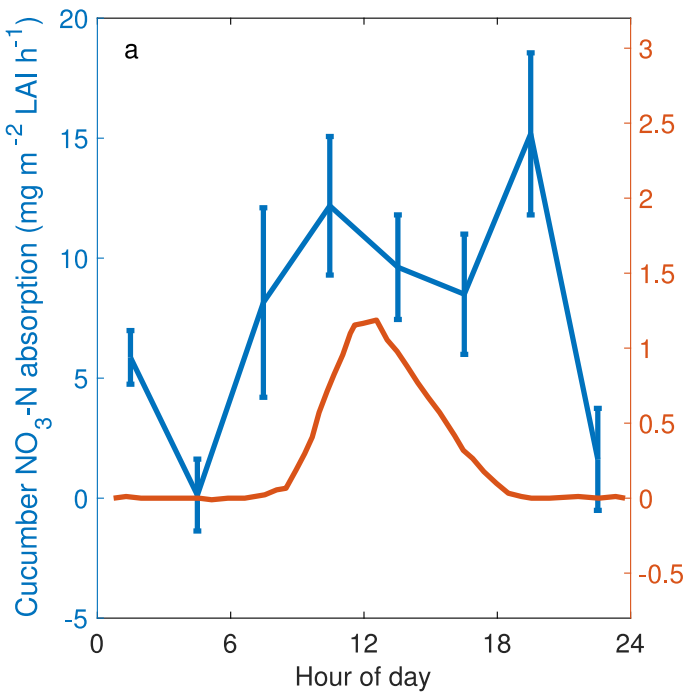

Fig. 2 a Observed diurnal pattern of cucumber nitrate uptake (with standard deviation) showing high uptake during the dark (Okuyama et al. 2015. LAI means leaf area index $\left(\mathrm{m}^{2} \mathrm{~m}^{-2}\right.$ ). b Observed seasonal pattern of tundra graminoid (Dupontia)

less frequently in nutrient-limited natural ecosystems. Nonetheless, in fertilization experiments, which often apply nutrients to levels much higher than natural inputs (e.g., Bouskill et al. 2014), or in agroecosystems where fertilizer is generally applied more than needed (Good and Beatty 2011), efflux could be significant. However, nutrient efflux is rarely considered in current terrestrial biogeochemical models. Ecosys is the only model we identified which explicitly prognoses this process, and showed that efflux may be important for accurately representing plant-microbial interactions (Grant 2013).

Many observations have quantified plant root nutrient acquisition dynamics during the non-growing season or leafless period (Table S2). One study suggested that in graminoid tundra ecosystems nearly half of the phosphate was taken up after plant shoots had begun senescence and translocating nutrients to roots for storage during winter Chapin and Bloom 1976; Chapin et al. 1975; Fig. 2b). In another study of a subarctic heath system, Larsen et al. (2012) used an ${ }^{15} \mathrm{~N}$-labeled glycine tracer and detected that graminoids, evergreen dwarf shrubs, and mosses were able to take up nitrogen during late winter and early spring, although with different temporal patterns. Nishitani et al. (2013) observed that a juvenile winter-green perennial herb actively took up nitrogen during its leafless period. Together, these observations confirm that plant root

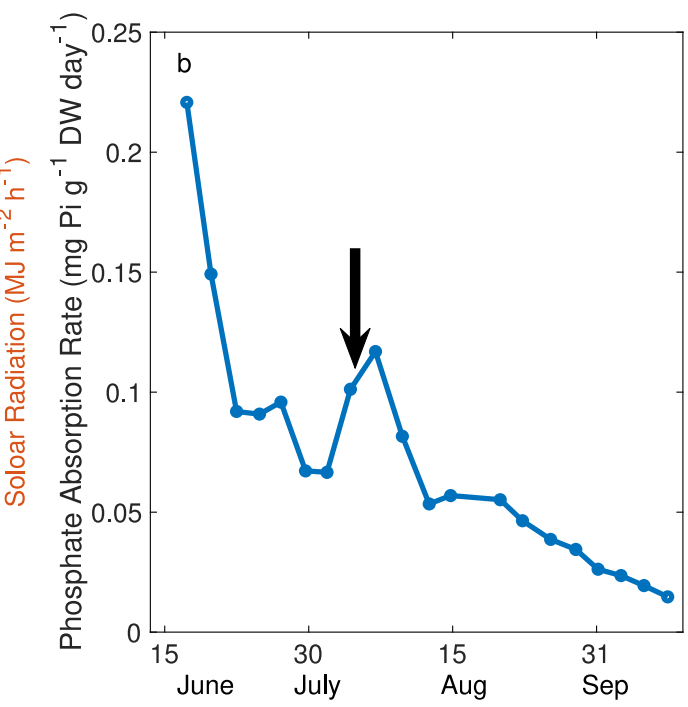

phosphate uptake showing that about half of the seasonal uptake occurred after plants started translocating nutrients to roots for winter storage (indicated by the thick black arrow;Chapin and Bloom 1976). DW means dry weight

nutrient acquisition and photosynthesis can occur independently and that, like microbes (e.g., Ji et al. 2015), plants maintain flexible nutrient stoichiometry.

\section{Updating the paradigm of plant root nutrient acquisition for terrestrial biogeochemical models}

Above we showed that both biogeochemical principles and observations suggest that plant root nutrient acquisition involves multiple kinetically-interacting nutrient forms, and is at most loosely coupled with instantaneous photosynthesis (i.e., plants maintain variable nutrient stoichiometry at the diurnal time scale). In particular, plants are able to take up nutrients in the absence of active photosynthesis. Therefore, the time lag between a plant signaling nutrient demand and taking up the nutrient by nutrient acquiring proteins is probably much greater than the numerical time step of most terrestrial biogeochemical models. We next examine how the relevant biogeochemical processes and in particular the asynchrony between photosynthesis and plant root nutrient uptake have been represented in the three modeling paradigms surveyed in this review.

The commonly applied relative demand approach assumes that plants maintain fixed nutrient stoichiometry in different organs during growth (thereby a synchronicity between plant root nutrient acquisition and 
photosynthesis) so that, for each numerical time step, a nutrient demand is computed based on a stoichiometric ratio with respect to new photosynthates (as net primary productivity) that cannot be balanced from nutrient translocation. Since the relative demand approach represents microbial nutrient demand analogously, it effectively assumes that microbes and plants are kinetically equivalent with respect to nutrient acquisition (i.e., no consideration of the kinetic difference in various nutrient acquiring proteins of plants and microbes). This approach would therefore not be able to resolve the observed diauxic growth of plants and microbes on various nutrients (e.g., Madigan et al. 2009; Taiz and Zeiger 2006). Rather, the relative demand approach either has to treat different nutrient forms as equally assimilable or force plants and microbes to take the nutrients with a presumed order (e.g., first ammonia, then nitrate, etc.). All these assumptions are inconsistent with the biogeochemical processes and observations reviewed above. Consequently, the traditional relative demand approach may at most be a good approximation at large time scales (e.g., monthly or seasonally), even though such a potential has not been demonstrated with observations. Therefore, considering that current terrestrial biogeochemical models often operate with 30 to 60 minute time steps, the existing relative demand approach is neither appropriate to represent the flexible nutrient stoichiometry of both plants and microbes, nor capable of resolving their diauxic growth on different nutrients.

The thermodynamic flux-force approach is firstprinciple based and was derived based on nonequilibrium thermodynamics (Thellier 1971). It has been proposed to explain the "dual mechanisms" of ionic nutrient uptake by higher plants, i.e., experimentalists often found that there are both high and lower affinity nutrient acquiring proteins when MichaelisMenten kinetics is used to fit observed nutrient uptake dynamics (Thellier et al. 2009). However, the thermodynamic flux-force approach relies on empirical regressions to account for the variability of its conductance parameters and it has yet to be applied in terrestrial biogeochemical models with coupled biogeochemical processes (Le Deunff et al. 2019). Therefore, it remains unclear how the thermodynamic flux-force approach can be applied consistently to resolve plant-microbe competition, although its similarity with the linlog kinetics (which has been used to model E. coli's central metabolism; Tusek and Kurtanjek 2010) suggests that such applications may be feasible. Nonetheless, the thermodynamic flux-force approach may have difficulty in resolving the diauxic growth on multiple substitutable nutrients (associated with NA1 and NA3; Fig. 1), even though it has the potential to resolve the asynchrony between photosynthesis and plant root nutrient uptake.

Unlike the relative demand approach and the thermodynamic flux-force approach, the capacity-based approach explicitly considers the three classes of processes affecting plant root nutrient acquisition (Fig. 1), and therefore allows for observed asynchrony between plant root nutrient acquisition and photosynthesis. In the capacity-based approach, nutrient uptake is decoupled from photosynthesis, and thus this approach is intrinsically compatible with the observation that plants are flexible in their organ and overall elemental stoichiometry (Mariotte et al. 2017). This flexibility allows the modeled plant to naturally include dynamic shoot-root nutrient and carbon exchanges and more advanced model representation of nutrient translocation (Grant 1998), thereby making the modeled system more realistically resilient to perturbations (Zaehle et al. 2014). Further, the capacity-based approach enables explicit incorporation of kinetic traits (e.g., affinity parameters and maximum uptake rates for substrates of nutrient acquiring proteins as have been used in the Michaelis-Menten kinetics) for both plants and microbes, providing a more direct link to biology. This approach thus extends the classic Nye-Tinker-Barber model that uses a single Michaelis-Menten kinetics to model nutrient uptake (Barber 1995; Roose et al. 2001; Tinker and Nye 2000), at the risk of including more model parameters (Zhu et al. 2017). However, the risk of including more model parameters can be alleviated by using improved mathematical formulations, e.g., the Equilibrium Chemistry Approximation (ECA) theory that is first-principle based and was derived from the law of mass action. ECA is an extension of the classic Michaelis-Menten kinetics for a network of many substrates and many consumers (Tang and Riley 2013, 2017), and enables a mechanistically tighter coupling between plants, microbes (including mycorrhizae), and soil abiotic factors (including diffusive nutrient transport; e.g., Tang and Riley 2019a, b). With the tighter coupling provided by ECA, the computed nutrient fluxes are less sensitive to individual model parameters than when the MichaelisMenten kinetics are used (as in the Nye-Tinker-Barber model). The parametric robustness of ECA over the Michaelis-Menten kinetics is discussed in detail in Tang 
and Riley $(2013,2017)$. Moreover, by explicitly considering internal nutrient concentrations, the capacitybased approach is also able to represent nutrient efflux, a feature that cannot be consistently incorporated into the relative demand approach (but can be resolved with the thermodynamic flux-force approach). Lastly, by incorporating the Goldman ionic flux equation (e.g., Bowman and Baglioni 1984), ECA (and therefore the capacity-based approach ) will be able to thermodynamically account for the "dual mechanisms" captured by the thermodynamic flux-force approach (Gerson and Poole 1971).

\section{Conclusions}

The relative demand, capacity-based approach, and thermodynamic flux-force approaches are three modeling paradigms that have been used to approximate the complex set of plant root nutrient acquisition processes operating in nature. As we describe here, only the capacity-based approach can comprehensively incorporate known soil and plant biogeochemistry and observed shoot-root asynchrony in nutrient uptake and phytomass synthesis, and has been successfully applied in several terrestrial biogeochemical models (Grant 2013; Medvigy et al. 2019; Yu et al. 2020; Zhu et al. 2019).

To further improve the modeling of nutrient regulation of plant and ecosystem biogeochemistry, additional observational and modeling developments are needed. Regarding observations, more measurements are needed of plant root nutrient acquisition, and plant shoot-root nutrient coupling in natural ecosystems for different plant species and ages and covering both diurnal and seasonal dynamics. Existing observations mostly focus on grasses and shrubs, while observations of diurnal and seasonal nutrient acquisition dynamics of trees are rare, and coverage of ecosystems in different geographical regions is sparse. Characterization of nutrient relevant traits (e.g., root nutrient acquiring protein density and capacity) and their trade-offs in more vegetation types and age groups are required to form a better representation of plant root nutrient acquisition. For modeling, new capacity-based algorithms should consider plant root nutrient acquisition regulation by plant stochiometric plasticity (e.g., Zhu et al. 2019), the close coupling between plant hydraulics and metabolite transport, and foliar nutrient uptake. Finally, more advanced numerical methods that enable close coupling of different plant-microbial processes should be explored (Tang and Riley 2016). With these developments, we expect that the modeling of nutrient regulation of terrestrial carbon-climate feedbacks can be made more realistic and accurate.

Supplementary Information The online version contains supplementary material available at https://doi.org/10.1007/s11104020-04798-5.

Acknowledgements This research was supported by the Director, Office of Science, Office of Biological and Environmental Research of the US Department of Energy under contract no. DEAC02-05CH11231 as part of their Regional and Global Climate Modeling program through the Reducing Uncertainties in Biogeochemical Interactions through Synthesis and Computation Scientific Focus Area (RUBISCO SFA) project and as part of the Energy Exascale Earth System Model (E3SM) project. The authors declare no conflict of interest.

Author contributions JYT and WJR conceived the idea and wrote the paper.

Open Access This article is licensed under a Creative Commons Attribution 4.0 International License, which permits use, sharing, adaptation, distribution and reproduction in any medium or format, as long as you give appropriate credit to the original author(s) and the source, provide a link to the Creative Commons licence, and indicate if changes were made. The images or other third party material in this article are included in the article's Creative Commons licence, unless indicated otherwise in a credit line to the material. If material is not included in the article's Creative Commons licence and your intended use is not permitted by statutory regulation or exceeds the permitted use, you will need to obtain permission directly from the copyright holder. To view a copy of this licence, visit http://creativecommons.org/licenses/by/4.0/.

\section{References}

Achat DL, Augusto L, Gallet-Budynek A, Loustau D (2016) Future challenges in coupled C-N-P cycle models for terrestrial ecosystems under global change: a review. Biogeochemistry 131:173-202. https://doi.org/10.1007 /s10533-016-0274-9

Al Harbi SF, Ghoneim AM, Modaihsh AS, Mahjoub MO (2013) Effect of foliar and soil application of phosphorus on phosphorus uptake, use efficiency and wheat grain yield in calcareous soil. J Appl Sci 13:188-192. https://doi.org/10.3923 jjas.2013.188.192

Albornoz F, Lieth JH (2015) Diurnal macronutrients uptake patterns by lettuce roots under various light and temperature levels. J Plant Nutr 38:2028-2043. https://doi.org/10.1080 /01904167.2015.1009098

Barber SA (1995) Soil nutrient bioavailability: a mechanistic approach. Wiley, New York 
Bouskill NJ, Riley WJ, Tang JY (2014) Meta-analysis of highlatitude nitrogen-addition and warming studies implies ecological mechanisms overlooked by land models. Biogeosciences 11:6969-6983. https://doi.org/10.5194/bg11-6969-2014

Bowman CL, Baglioni A (1984) Application of the GoldmanHodgkin-Katz current equation to membrane current voltage data. J Theor Biol 108:1-29. https://doi.org/10.1016/S00225193(84)80165-4

Bucher M, Rausch C, Daram P (2001) Molecular and biochemical mechanisms of phosphorus uptake into plants. J Plant Nutr Soil Sc 164: 209-217. https://doi.org/10.1002/1522-2624 (200104)164:2<209::Aid-Jpln209>3.3.Co;2-6.

Chapin FS, Bloom A (1976) Phosphate absorption - adaptation of tundra graminoids to a low-temperature, low phosphorus environment. Oikos 27:111-121. https://doi.org/10.2307 13543439

Chapin FS, van Cleve K, Tieszen LL (1975) Seasonal nutrient dynamics of tundra vegetation at Barrow, Alaska. Arct Alp Res 7:209-226. https://doi.org/10.1080 /00040851.1975.12003828

Cronan CS (2018) Ecosystem biogeochemistry: element cycling in forest landscape. Springer, Cham

Erickson DW, Schink SJ, Patsalo V, Williamson JR, Gerland U, Hwa T (2017) A global resource allocation strategy governs growth transition kinetics of Escherichia coli. Nature 551: 119-123. https://doi.org/10.1038/nature24299

Feng HM, Fan XR, Miller AJ, Xu GH (2020) Plant nitrogen uptake and assimilation: regulation of cellular $\mathrm{pH}$ homeostasis. J Exp Bot 71:4380-4392. https://doi.org/10.1093 /jxb/eraa150

Fernandez V, Brown PH (2013) From plant surface to plant metabolism: the uncertain fate of foliar-applied nutrients. Front Plant Sci 4. ARTN 289 https://doi.org/10.3389 /fpls.2013.00289

Fleischer K, Rammigl A, De Kauwe MG, Walker AP, Domingues TF, Fuchslueger L, Garcia S, Goll DS, Grandis A, Jiang MK, Haverd V, Hofhansl F, Holm JA, Kruijt B, Leung F, Medlyn BE, Mercado LM, Norby RJ, Pak B, von Randow C, Quesada CA, Schaap KJ, Valverde-Barrantes OJ, Wang YP, Yang XJ, Zaehle S, Zhu Q, Lapola DM (2019) Amazon forest response to $\mathrm{CO} 2$ fertilization dependent on plant phosphorus acquisition. Nat Geosci 12:736-741. https://doi.org/10.1038/s41561-019-0404-9

Franklin O, Cambui CA, Gruffman L, Palmroth S, Oren R, Nasholm T (2017) The carbon bonus of organic nitrogen enhances nitrogen use efficiency of plants. Plant Cell Environ 40:25-35. https://doi.org/10.1111/pce.12772

Furihata T, Suzuki M, Sakurai H (1992) Kinetic characterization of 2 phosphate-uptake systems with different affinities in suspension-cultured catharanthus-roseus protoplasts. Plant Cell Physiol 33:1151-1157

Garcia NS, Bonachela JA, Martiny AC (2016) Interactions between growth-dependent changes in cell size, nutrient supply and cellular elemental stoichiometry of marine Synechococcus. Isme J 10:2715-2724. https://doi. org/10.1038/ismej.2016.50

Gent L, Forde BG (2017) How do plants sense their nitrogen status? J Exp Bot 68:2531-2539. https://doi.org/10.1093 /jxb/erx013
Gerson DF, Poole RJ (1971) Anion absorption by plants - unary interpretation of dual mechanisms. Plant Physiol 48:509511. https://doi.org/10.1104/pp.48.4.509

Goll DS, Brovkin V, Parida BR, Reick CH, Kattge J, Reich PB, van Bodegom PM, Niinemets U (2012) Nutrient limitation reduces land carbon uptake in simulations with a model of combined carbon, nitrogen and phosphorus cycling. Biogeosciences 9:3547-3569. https://doi.org/10.5194/bg-93547-2012

Good AG, Beatty PH (2011) Fertilizing nature: a tragedy of excess in the commons. PLos Biol 9: ARTN e1001124. https://doi. org/10.1371/journal.pbio.1001124

Grant RF (1998) Simulation in ecosys of root growth response to contrasting soil water and nitrogen. Ecol Model 107:237264. https://doi.org/10.1016/S0304-3800(97)00221-4

Grant RF (2013) Modelling changes in nitrogen cycling to sustain increases in forest productivity under elevated atmospheric $\mathrm{CO} 2$ and contrasting site conditions. Biogeosciences 10: 7703-7721. https://doi.org/10.5194/bg-10-7703-2013

Hidy D, Barcza Z, Marjanovic H, Sever MZO, Dobor L, Gelybo G, Fodor N, Pinter K, Churkina G, Running S, Thornton P, Bellocchi G, Haszpra L, Horvath F, Suyker A, Nagy Z (2016) Terrestrial ecosystem process model BiomeBGCMuSo v4.0: summary of improvements and new modeling possibilities. Geosci Model Dev 9:4405-4437. https://doi.org/10.5194/gmd-9-4405-2016

Houshmandfar A, Fitzgerald GJ, O'Leary G, Tausz-Posch S, Fletcher A, Tausz M (2018) The relationship between transpiration and nutrient uptake in wheat changes under elevated atmospheric CO2. Physiol Plant 163:516-529. https://doi. org/10.1111/ppl.12676

Jensen KH, Berg-Sorensen K, Bruus H, Holbrook NM, Liesche J, Schulz A, Zwieniecki MA, Bohr T (2016) Sap flow and sugar transport in plants. Rev Mod Phys 88: ARTN 035007. https://doi.org/10.1103/RevModPhys.88.035007

Ji B, Yang K, Zhu L, Jiang Y, Wang HY, Zhou J, Zhang HN (2015) Aerobic denitrification: A review of important advances of the last 30 years. Biotechnol Bioproc E 20:643651. https://doi.org/10.1007/s12257-015-0009-0

Jing H, Zhou HX, Wang GL, Xue S, Liu GB, Duan MC (2017) Nitrogen addition changes the stoichiometry and growth rate of different organs in Pinus tabuliformis seedlings. Front Plant Sci 8: ARTN 1922. https://doi.org/10.3389 /fpls.2017.01922

Jordan MO, Habib R, Bonafous M (1998) Uptake and allocation of nitrogen in young peach trees as affected by the amount of photosynthates available in roots. J Plant Nutr 21:24412454. https://doi.org/10.1080/01904169809365576

Kannan S, Charnel A (1986) Foliar absorption and transport of inorganic nutrients. Crit Rev Plant Sci 4:341-375. https://doi. org/10.1080/07352688609382231

Kattge J, Diaz S, Lavorel S, Prentice C, Leadley P, Bonisch G, Garnier E, Westoby M, Reich PB, Wright IJ, Cornelissen JHC, Violle C, Harrison SP, van Bodegom PM, Reichstein M, Enquist BJ, Soudzilovskaia NA, Ackerly DD, Anand M, Atkin O, Bahn M, Baker TR, Baldocchi D, Bekker R, Blanco CC, Blonder B, Bond WJ, Bradstock R, Bunker DE, Casanoves F, Cavender-Bares J, Chambers JQ, Chapin FS, Chave J, Coomes D, Cornwell WK, Craine JM, Dobrin BH, Duarte L, Durka W, Elser J, Esser G, Estiarte M, Fagan WF, Fang J, Fernandez-Mendez F, Fidelis A, Finegan B, Flores O, 
Ford H, Frank D, Freschet GT, Fyllas NM, Gallagher RV, Green WA, Gutierrez AG, Hickler T, Higgins SI, Hodgson JG, Jalili A, Jansen S, Joly CA, Kerkhoff AJ, Kirkup D, Kitajima K, Kleyer M, Klotz S, Knops JMH, Kramer K, Kuhn I, Kurokawa H, Laughlin D, Lee TD, Leishman M, Lens F, Lenz T, Lewis SL, Lloyd J, Llusia J, Louault F, Ma S, Mahecha MD, Manning P, Massad T, Medlyn BE, Messier J, Moles AT, Muller SC, Nadrowski K, Naeem S, Niinemets U, Nollert S, Nuske A, Ogaya R, Oleksyn J, Onipchenko VG, Onoda Y, Ordonez J, Overbeck G, Ozinga WA, Patino S, Paula S, Pausas JG, Penuelas J, Phillips OL, Pillar V, Poorter H, Poorter L, Poschlod P, Prinzing A, Proulx R, Rammig A, Reinsch S, Reu B, Sack L, Salgado-Negre B, Sardans J, Shiodera S, Shipley B, Siefert A, Sosinski E, Soussana JF, Swaine E, Swenson N, Thompson K, Thornton P, Waldram M, Weiher E, White M, White S, Wright SJ, Yguel B, Zaehle S, Zanne AE, Wirth C (2011) TRY - a global database of plant traits. Global Change Biol 17:2905-2935. https://doi. org/10.1111/j.1365-2486.2011.02451.x

la Cecilia D, Riley WJ, Maggi F (2019) Biochemical modeling of microbial memory effects and catabolite repression on soil organic carbon compounds. Soil Biol Biochem 128:1-12. https://doi.org/10.1016/j.soilbio.2018.10.003

Lambers H, Mougel C, Jaillard B, Hinsinger P (2009) Plantmicrobe-soil interactions in the rhizosphere: an evolutionary perspective. Plant Soil 321:83-115. https://doi.org/10.1007 /s11104-009-0042-x

Larsen KS, Michelsen A, Jonasson S, Beier C, Grogan P (2012) Nitrogen uptake during fall, winter and spring differs among plant functional groups in a subarctic heath ecosystem. Ecosystems 15:927-939. https://doi.org/10.1007/s10021012-9555-x

Lawrence DM, Fisher RA, Koven CD, Oleson KW, Swenson SC, Bonan G, Collier N, Ghimire B, van Kampenhout L, Kennedy D, Kluzek E, Lawrence PJ, Li F, Li HY, Lombardozzi D, Riley WJ, Sacks WJ, Shi MJ, Vertenstein M, Wieder WR, Xu CG, Ali AA, Badger AM, Bisht G, van den Broeke M, Brunke MA, Burns SP, Buzan J, Clark M, Craig A, Dahlin K, Drewniak B, Fisher JB, Flanner M, Fox AM, Gentine P, Hoffman F, Keppel-Aleks G, Knox R, Kumar S, Lenaerts J, Leung LR, Lipscomb WH, Lu YQ, Pandey A, Pelletier JD, Perket J, Randerson JT, Ricciuto DM, Sanderson BM, Slater A, Subin ZM, Tang JY, Thomas RQ, Martin MV, Zeng XB (2019) The community land model version 5: Description of new features, benchmarking, and impact of forcing uncertainty. J Adv Model Earth Sy 11:4245-4287. https://doi.org/10.1029 /2018ms001583

Le Deunff E, Malagoli P, Decau ML (2019) Modelling nitrogen uptake in plants and phytoplankton: advantages of integrating flexibility into the spatial and temporal dynamics of nitrate absorption. Agronomy-Basel 9: ARTN 116. https://doi.org/10.3390/agronomy9030116

Lee RB, Drew MC (1989) Rapid, reversible inhibition of nitrate influx in barley by ammonium. J Exp Bot 40:741-752. https://doi.org/10.1093/jxb/40.7.741

Maathuis FJM (2009) Physiological functions of mineral macronutrients. Curr Opin Plant Biol 12:250-258. https://doi. org/10.1016/j.pbi.2009.04.003
Madigan MT, Martinko JM, Dunlap PV, Clark DP (2009) Brock biology of microorganisms, 12 edn. Pearson Eduction, Inc., San Francisco

Mariotte P, Canarini A, Dijkstra FA (2017) Stoichiometric N:P flexibility and mycorrhizal symbiosis favour plant resistance against drought. J Ecol 105:958-967. https://doi.org/10.1111 /1365-2745.12731

Masclaux-Daubresse C, Daniel-Vedele F, Dechorgnat J, Chardon F, Gaufichon L, Suzuki A (2010) Nitrogen uptake, assimilation and remobilization in plants: challenges for sustainable and productive agriculture. Ann Bot-London 105:1141-1157. https://doi.org/10.1093 /aob/mcq028

Mckercher RB, Tollefson TS (1978) Barley response to phosphorus from phospholipids and nucleic-acids. Can J Soil Sci 58: 103-105. https://doi.org/10.4141/cjss78-011

Medvigy D, Wang GS, Zhu Q, Riley WJ, Trierweiler AM, Waring BG, Xu XT, Powers JS (2019) Observed variation in soil properties can drive large variation in modelled forest functioning and composition during tropical forest secondary succession. New Phytol 223:1820-1833. https://doi. org/10.1111/nph.15848

Mencuccini M, Holtta T (2010) The significance of phloem transport for the speed with which canopy photosynthesis and belowground respiration are linked. New Phytol 185:189203. https://doi.org/10.1111/j.1469-8137.2009.03050.x

Miller AJ, Cramer MD (2004) Root nitrogen acquisition and assimilation. Plant Soil 274:1-36. https://doi.org/10.1007 /s11104-004-0965-1

Nasholm T, Kielland K, Ganeteg U (2009) Uptake of organic nitrogen by plants. New Phytol 182:31-48. https://doi. org/10.1111/j.1469-8137.2008.02751.x

Niemietz CM, Tyerman SD (2000) Channel-mediated permeation of ammonia gas through the peribacteroid membrane of soybean nodules. Febs Lett 465:110-114. https://doi. org/10.1016/S0014-5793(99)01729-9

Nishitani S, Nakamura T, Kachi N (2013) Nitrogen uptake during the leafless period in juvenile plants of a winter-green perennial herb, Lycoris radiata var. radiata (Amaryllidaceae). Botany 91:715-721. https://doi.org/10.1139/cjb-2013-0021

Okuyama Y, Ozawa K, Takagaki M (2015) Diurnal changes in nitrogen and potassium absorption rates of plants grown in a greenhouse. J Agric Meteorol 71:256-262. https://doi. org/10.2480/agrmet.D-14-00039

Oldroyd GED, Leyser O (2020) A plant's diet, surviving in a variable nutrient environment. Science 368:45-52. ARTN eaba0196. https://doi.org/10.1126/science.aba0196

Pan WL, Teyker RH, Jackson WA, Moll RH (1987) Diurnalvariation in nitrate, potassium, and phosphate-uptake in maize seedlings - considerations in screening genotypes for uptake efficiency. J Plant Nutr 10:1819-1833. https://doi. org/10.1080/01904168709363723

Pinton R, Tomasi N, Zanin L (2016) Molecular and physiological interactions of urea and nitrate uptake in plants. Plant Signal Behav 11. https://doi.org/10.1080/15592324.2015.1076603

Raven JA, Smith FA (1976) Nitrogen assimilation and transport in vascular land plants in relation to intracellular $\mathrm{pH}$ regulation. New Phytol 76:415-431. https://doi.org/10.1111/j.14698137.1976.tb01477.x

Riley WJ, Zhu Q, Tang JY (2018) Weaker land-climate feedbacks from nutrient uptake during photosynthesis-inactive periods. 
Nat Clim Change 8:1002-1006. https://doi.org/10.1038 /s41558-018-0325-4

Roose T, Fowler AC, Darrah PR (2001) A mathematical model of plant nutrient uptake. J Math Biol 42:347-360. https://doi. org/10.1007/s002850000075

Schachtman DP, Reid RJ, Ayling SM (1998) Phosphorus uptake by plants: From soil to cell. Plant Physiol 116:447-453. https://doi.org/10.1104/pp.116.2.447

Schimel JP, Jackson LE, Firestone MK (1989) Spatial and temporal effects on plant microbial competition for inorganic nitrogen in a California annual grassland. Soil Biol Biochem 21:1059-1066. https://doi.org/10.1016/0038-0717 (89)90044-8

Smith FW (2002) The phosphate uptake mechanism. Plant Soil 245:105-114. https://doi.org/10.1023/A:1020660023284

Sparks JP (2009) Ecological ramifications of the direct foliar uptake of nitrogen. Oecologia 159:1-13. https://doi. org/10.1007/s00442-008-1188-6

Taiz L, Zeiger E (2006) Plan physiology, 4th edn. Sinauer Associates, Inc., Sunderland

Tang JY, Riley WJ (2013) A total quasi-steady-state formulation of substrate uptake kinetics in complex networks and an example application to microbial litter decomposition. Biogeosciences 10:8329-8351. https://doi.org/10.5194/bg10-8329-2013

Tang JY, Riley WJ (2016) Technical Note: A generic law-of-theminimum flux limiter for simulating substrate limitation in biogeochemical models. Biogeosciences 13:723-735. https://doi.org/10.5194/bg-13-723-2016

Tang JY, Riley WJ (2017) SUPECA kinetics for scaling redox reactions in networks of mixed substrates and consumers and an example application to aerobic soil respiration. Geosci Model Dev 10:3277-3295. https://doi.org/10.5194/gmd-103277-2017

Tang JY, Riley WJ (2019a) Competitor and substrate sizes and diffusion together define enzymatic depolymerization and microbial substrate uptake rates. Soil Biol Biochem 139: ARTN 107624.https://doi.org/10.1016/j. soilbio.2019.107624

Tang JY, Riley WJ (2019b) A theory of effective microbial substrate affinity parameters in variably saturated soils and an example application to aerobic soil heterotrophic respiration. J Geophys Res-Biogeo 124:918-940. https://doi. org/10.1029/2018jg004779

Tegeder M, Masclaux-Daubresse C (2018) Source and sink mechanisms of nitrogen transport and use. New Phytol 217:35-53. https://doi.org/10.1111/nph.14876

Thellier M (1971) Non-equilibrium thermodynamics and electrokinetic interpretation of biological systems. J Theor Biol 31: 389-389. https://doi.org/10.1016/0022-5193(71)90017-8

Thellier M, Ripoll C, Norris V, Nikolic M, Romheld V (2009) Solute uptake in plants: A flow/force interpretation. In: Luttge U, Beyschlag W, Budel B, Francis D (eds) Progress in Botany. Springer, Berlin/Heidelberg

Tinker PB, Nye PH (2000) Solute movement in the rhizosphere, 2nd edn. Oxford University Press, Oxford

Tusek A, Kurtanjek Z (2010) Lin-log model of E-coli central metabolism. Acta Chim Slov 57:52-59 van Veen JA, Ladd JN, Martin JK, Amato M (1987) Turnover of carbon, nitrogen and phosphorus through the microbial biomass in soils incubated with C-14-labeled, N-15-labeled and P-32 labeled bacterial-cells. Soil Biol Biochem 19:559-565. https://doi.org/10.1016/0038-0717(87)90099-X

Wang YP, Law RM, Pak B (2010) A global model of carbon, nitrogen and phosphorus cycles for the terrestrial biosphere. Biogeosciences 7:2261-2282. https://doi.org/10.5194/bg-72261-2010

Watanabe T (2002) Pictorial atlas of soil and seed fungi: Morphologies of cultured fungi and key to species. CPC Press, Boca Raton

Witte CP (2011) Urea metabolism in plants. Plant Sci 180:431438. https://doi.org/10.1016/j.plantsci.2010.11.010

Wittwer SH, Teubner FG (1959) Foliar absorption of mineral nutrients. Annu Rev Plant Phys 10:13-32. https://doi. org/10.1146/annurev.pp.10.060159.000305

Yang X, Thornton PE, Ricciuto DM, Post WM (2014) The role of phosphorus dynamics in tropical forests - a modeling study using CLM-CNP. Biogeosciences 11:1667-1681. https://doi. org/10.5194/bg-11-1667-2014

Yu L, Ahrens B, Wutzler T, Schrumpf M, Zaehle S (2020) Jena Soil Model (JSM v1.0; revision 1934): a microbial soil organic carbon model integrated with nitrogen and phosphorus processes. Geosci Model Dev 13:783-803. https://doi. org/10.5194/gmd-13-783-2020

Zaehle S, Medlyn BE, De Kauwe MG, Walker AP, Dietze MC, Hickler T, Luo YQ, Wang YP, El-Masri B, Thornton P, Jain A, Wang SS, Warlind D, Weng ES, Parton W, Iversen CM, Gallet-Budynek A, McCarthy H, Finzi AC, Hanson PJ, Prentice IC, Oren R, Norby RJ (2014) Evaluation of 11 terrestrial carbon-nitrogen cycle models against observations from two temperate Free-Air CO2 Enrichment studies. New Phytol 202:803-822. https://doi.org/10.1111/nph.12697

Zanin L, Zamboni A, Monte R, Tomasi N, Varanini Z, Cesco S, Pinton R (2015) Transcriptomic analysis highlights reciprocal interactions of urea and nitrate for nitrogen acquisition by maize roots. Plant Cell Physiol 56:532-548. https://doi. org $/ 10.1093 /$ pcp/pcu202

Zhu Q, Riley WJ, Tang J, Koven CD (2016) Multiple soil nutrient competition between plants, microbes, and mineral surfaces: model development, parameterization, and example applications in several tropical forests. Biogeosciences 13:341-363. https://doi.org/10.5194/bg-13-341-2016

Zhu Q, Riley WJ, Tang JY (2017) A new theory of plant-microbe nutrient competition resolves inconsistencies between observations and model predictions. Ecol Appl 27:875-886. https://doi.org/10.1002/eap.1490

Zhu Q, Riley WJ, Tang JY, Collier N, Hoffman FM, Yang XJ, Bisht G (2019) Representing nitrogen, phosphorus, and carbon interactions in the E3SM land model: development and dlobal benchmarking. J Adv Model Earth Sy 11:2238-2258. https://doi.org/10.1029/2018ms001571

Publisher's Note Springer Nature remains neutral with regard to jurisdictional claims in published maps and institutional affiliations. 